Dhaka Univ. J. Biol. Sci. 25(2): 131-138, 2016 (July)

\title{
GROWTH ANALYSIS OF WHEAT VAR. BARI GOM-26 AS AFFECTED BY FOLIAR SPRAY OF NAA AT DIFFERENT NITROGEN FERTILIZER LEVELS
}

\author{
SAIFUl IsLAM AND NARGIS JAHAN* \\ Plant Physiology Laboratory, Department of Botany, University of Dhaka, \\ Dhaka-1000, Bangladesh
}

Key words: BARI GOM-26, NAA, Foliar application, Growth analysis

\begin{abstract}
Leaf area index (LAI), crop growth rate (CGR), relative growth rate (RGR), net assimilation rate (NAR) and leaf area duration (LAD) of a variety of wheat (Triticum aestivum L.) were studied with three concentrations ( 0,25 and $50 \mathrm{ppm})$ of naphthalene acetic acid (NAA) and four levels $(0,50,75$ and $100 \%)$ of Nfertilizer in a field experiment during 2014 - 2015. Results showed that LAI and LAD at all stages of growth increased from control and their peak values were recorded mostly from 25 ppm NAA in combination with $75 \% \mathrm{~N}$-fertilizer and 50 ppm NAA in combination with $50 \% \mathrm{~N}$-fertilizer. RGR was affected both positively and negatively depending on the concentration of NAA and nitrogen levels and was higher at earlier age (15 to 45 DAS) as opposed to later stage irrespective of treatments. CGR and NAR were also affected positively and negatively and tended to increase sharply reaching maximum at 30 - 45 DAS with a few exceptions and then decreased for most of the treatments with the progression of age. At 30 - 45 DAS, peak value of CGR was recorded from 25 ppm NAA in combination with $75 \% \mathrm{~N}$-fertilizer. Of all the treatments, $25 \mathrm{ppm}$ NAA in combination with $75 \% \mathrm{~N}$-fertilizer produced better stimulation.
\end{abstract}

\section{Introduction}

The classical concept of physiological basis of variation in crop yield nourishes the idea that the differences in crop yield in an environment is the ultimate reflection of variation in different growth processes of the successive stages of crop development. Such variations in growth processes can be efficiently measured by quantifying the different components of growth, collectively known as growth analysis ${ }^{(1-3)}$. A combination of these growth components not only states how plant accumulates dry matter, but also reveals the events which can make a plant more or less productive singly or in population(4). Crop growth processes viz., CGR, RGR and NAR control dry matter production and ultimately reflected in the yield(5,6). LAI and LAD are important morphological index of plant leaf which are closely connected with photosynthetic activity of leaves and control dry matter production(7). NAA, a synthetic growth

*Author for correspondence: <jahan.nargis@yahoo.com>. 
regulator, at appropriate concentration has proved its potentiality to substantially influence these growth parameters in different plants viz., chickpea ${ }^{(8)}$, rice ${ }^{(9)}$. Use of Nfertilizer is also important for proper growth and development. But, recently fertilizer management has drawn the attention of plant scientists all over the world. NAA in combination with nitrogen fertilizer can be an important way to serve this purpose. A report regarding their combined effects on plant growth is also available ${ }^{(10)}$. However, growth and growth attributes of wheat in relation to NAA at different nitrogen fertilizer levels are yet to be available in Bangladesh. Thus, an attempt was made to evaluate the effect of NAA at different nitrogen levels on some growth parameters of BARI GOM-26.

\section{Materials and Methods}

A field experiment was carried out at the Botanical Garden of the Department of Botany, University of Dhaka during November, 2014 to March, 2015. The experimental soil was analyzed and high levels of phosphorus and low levels of nitrogen and potassium were recorded ${ }^{(11)}$. Cow-dung, TSP, MP and gypsum were applied as basal dose during land preparation. The experiment was laid out in RCBD with five replications. Seeds of BARI GOM-26 were collected from Bangladesh Agricultural Research Institute (BARI), Joydebpur, Gazipur. The experiment comprised of 12 treatment combinations where, three concentrations of NAA viz., without NAA ( $\left.\mathrm{G}_{0}\right), 25$ ppm NAA $\left(\mathrm{G}_{1}\right)$ and 50 ppm NAA $\left(\mathrm{G}_{2}\right)$, and four levels of N-fertilizer viz., without any $\mathrm{N}$-fertilizer $\left(\mathrm{F}_{0}\right), 50 \%$ of the recommended dose $\left(\mathrm{F}_{1}\right), 75 \%$ of the recommended dose $\left(\mathrm{F}_{2}\right)$ and full recommended dose of urea $\left(\mathrm{F}_{3}\right)$ were used. Two-thirds of the urea were used as basal and the rest onethird was applied at 25 days after sowing. Seeds were sterilized with $0.05 \%$ calcium hypochlorite solution for five minutes and repeatedly washed in tap water and finally with distilled water to remove any trace of calcium hypochlorite. Seeds were sown on November 8,2014 . Weeding was done at the age of 18 days followed by thinning to keep plant to plant distance of $10 \mathrm{~cm}$. Irrigation was also done as and when necessary. NAA treatments were applied as foliar spray at the age of 30 days.

Data on leaf area index (LAI), leaf area duration (LAD), crop growth rate (CGR), relative growth rate (RGR) and net assimilation rate (NAR)were recorded from the age of 15 days after spray (DAS) up to 75 DAS at an interval of 15 days. Leaf area (LA) was measured by length width method according to Voldeng and Simpson(12). LAI, CGR, LAD were calculated following the formula of Yoshida et al.(13), Watson ${ }^{(14)}$ and Power et al.(15), respectively. RGR and NAR were calculated using the formula of Williams ${ }^{(16)}$. Data were analyzed statistically(17) and treatment means were compared by LSD test at $5 \%$ level of significance. 


\section{Results and Discussion}

Results presented in Table 1 revealed that leaf area index (LAI) increased in all the treatments from the control $\left(\mathrm{G}_{0} \mathrm{~F}_{0}\right)$ at all the ages and was significantly affected at 15,30 and 45 DAS. Application of 50 ppm NAA in combination with $50 \%$ N-fertilizer resulted in the maximum LAI at 15, 60 and 75 DAS, respectively whereas maximum LAI at 30 and 45 DAS were found due to 25 ppm NAA in combination with $75 \% \mathrm{~N}$-fertilizer. Application of N-fertilizer alone gave higher leaf area index as compared with NAA application alone. Increase in LAI following NAA and N-fertilizer application has also been reported in paddy(10). Patil et al.(18) obtained higher LAI in chickpea with $20 \mathrm{ppm}$ NAA. Karim and Fattah ${ }^{(8)}$ reported both increase and decrease in LAI following NAA application in chickpea.

Table 1. Effect of NAA at different nitrogen levels on leaf area index (LAI) of BARI GOM-26 at different days after spray.

\begin{tabular}{llllll}
\hline \multirow{2}{*}{ Treatments } & \multicolumn{5}{c}{ Days after spray (DAS) } \\
\cline { 2 - 6 } & 15 & 30 & 45 & 60 & 75 \\
\hline $\mathrm{G}_{0} \mathrm{~F}_{0}$ & $0.58 \mathrm{~g}$ & $0.51 \mathrm{e}$ & $0.59 \mathrm{~g}$ & 0.81 & 0.81 \\
$\mathrm{G}_{0} \mathrm{~F}_{1}$ & $0.95 \mathrm{~b}-\mathrm{f}$ & $0.99 \mathrm{a}-\mathrm{g}$ & $1.23 \mathrm{abc}$ & 1.15 & 1.14 \\
$\mathrm{G}_{0} \mathrm{~F}_{2}$ & $1.06 \mathrm{abc}$ & $1.01 \mathrm{a}-\mathrm{e}$ & $1.24 \mathrm{ab}$ & 1.28 & 1.27 \\
$\mathrm{G}_{0} \mathrm{~F}_{3}$ & $1.02 \mathrm{bcd}$ & $1.03 \mathrm{a}-\mathrm{d}$ & $1.04 \mathrm{a}-\mathrm{f}$ & 1.21 & 1.20 \\
$\mathrm{G}_{1} \mathrm{~F}_{0}$ & $0.91 \mathrm{~b}-\mathrm{g}$ & $0.82 \mathrm{a}-\mathrm{e}$ & $0.94 \mathrm{a}-\mathrm{g}$ & 1.11 & 1.11 \\
$\mathrm{G}_{1} \mathrm{~F}_{1}$ & $1.00 \mathrm{~b}-\mathrm{e}$ & $1.04 \mathrm{abc}$ & $1.12 \mathrm{a}-\mathrm{e}$ & 1.15 & 1.15 \\
$\mathrm{G}_{1} \mathrm{~F}_{2}$ & $1.16 \mathrm{ab}$ & $1.13 \mathrm{a}$ & $1.34 \mathrm{a}$ & 1.47 & 1.46 \\
$\mathrm{G}_{1} \mathrm{~F}_{3}$ & $0.95 \mathrm{~b}-\mathrm{f}$ & $1.00 \mathrm{a}-\mathrm{f}$ & $0.92 \mathrm{~b}-\mathrm{g}$ & 1.09 & 1.08 \\
$\mathrm{G}_{2} \mathrm{~F}_{0}$ & $0.71 \mathrm{~d}-\mathrm{g}$ & $0.76 \mathrm{~b}-\mathrm{e}$ & $0.85 \mathrm{~b}-\mathrm{g}$ & 0.98 & 0.98 \\
$\mathrm{G}_{2} \mathrm{~F}_{1}$ & $1.38 \mathrm{a}$ & $1.06 \mathrm{ab}$ & $1.18 \mathrm{a}-\mathrm{d}$ & 1.52 & 1.51 \\
$\mathrm{G}_{2} \mathrm{~F}_{2}$ & $0.86 \mathrm{~b}-\mathrm{g}$ & $0.81 \mathrm{~b}-\mathrm{e}$ & $0.96 \mathrm{a}-\mathrm{g}$ & 1.19 & 1.18 \\
$\mathrm{G}_{2} \mathrm{~F}_{3}$ & $0.77 \mathrm{c}-\mathrm{g}$ & $0.81 \mathrm{~b}-\mathrm{e}$ & $0.92 \mathrm{~b}-\mathrm{g}$ & 1.06 & 1.06 \\
$\mathrm{CV}(\%)$ & 41.62 & 37.23 & 38.39 & 36.63 & 36.52 \\
$\mathrm{LSD}_{5}(0.05)$ & 0.34 & 0.31 & 0.40 & $\mathrm{NS}$ & $\mathrm{NS}$ \\
\hline
\end{tabular}

Means in a vertical column followed by same letter do not differ significantly at 5\% level.

LAD describes the total amount of leaf area present over a particular period of growth and is directly correlated with dry matter production. It has been observed that any practice that increases the longevity of green leaves should increase the dry weight of plants. Table 2 revealed that application of NAA at different nitrogen levels significantly affected LAD throughout the investigation period except at 60 - 75 DAS. LAD increased over the control at all the growth ages. At 15 - 30 and $60-75$ DAS maximum LAD values were found due to $50 \mathrm{ppm}$ NAA in combination with $50 \% \mathrm{~N}$ - 
fertilizer. Whereas, at $30-45$ and 45 - 60 DAS significantly highest LAD was obtained from 25 ppm NAA in combination with $75 \% \mathrm{~N}$-fertilizer. LAD showed an increasing trend as the plants aged except due to $\mathrm{G}_{0} \mathrm{~F}_{1}$ and $\mathrm{G}_{0} \mathrm{~F}_{2}$ at 60 - 75 DAS. Increase in LAD following NAA application was also reported in chickpea by Karim and Fattah( ${ }^{(8)}$ and in okra by Surendra et al.(19).

Fig. 1 showed that CGR was higher at the initial stage of growth and then declined till maturity. CGR was affected both positively and negatively and showed substantial differences over the growth stages. CGR increased sharply at 30 - 45 DAS following all the treatments except $\mathrm{G}_{1} \mathrm{~F}_{0}, \mathrm{G}_{2} \mathrm{~F}_{0}$ and $\mathrm{G}_{2} \mathrm{~F}_{2}$ as against control. Reduction in crop growth rate with plant age was probably due to cessation of vegetative growth, loss of leaves, and senescence. The peak crop growth rate was recorded at 15 - 30 and 30 - 45 DAS from 25 ppm NAA in combination with $75 \%$ N-fertilizer. Similar results of increase and decrease in CGR following NAA application was reported in chickpea ${ }^{(8)}$.

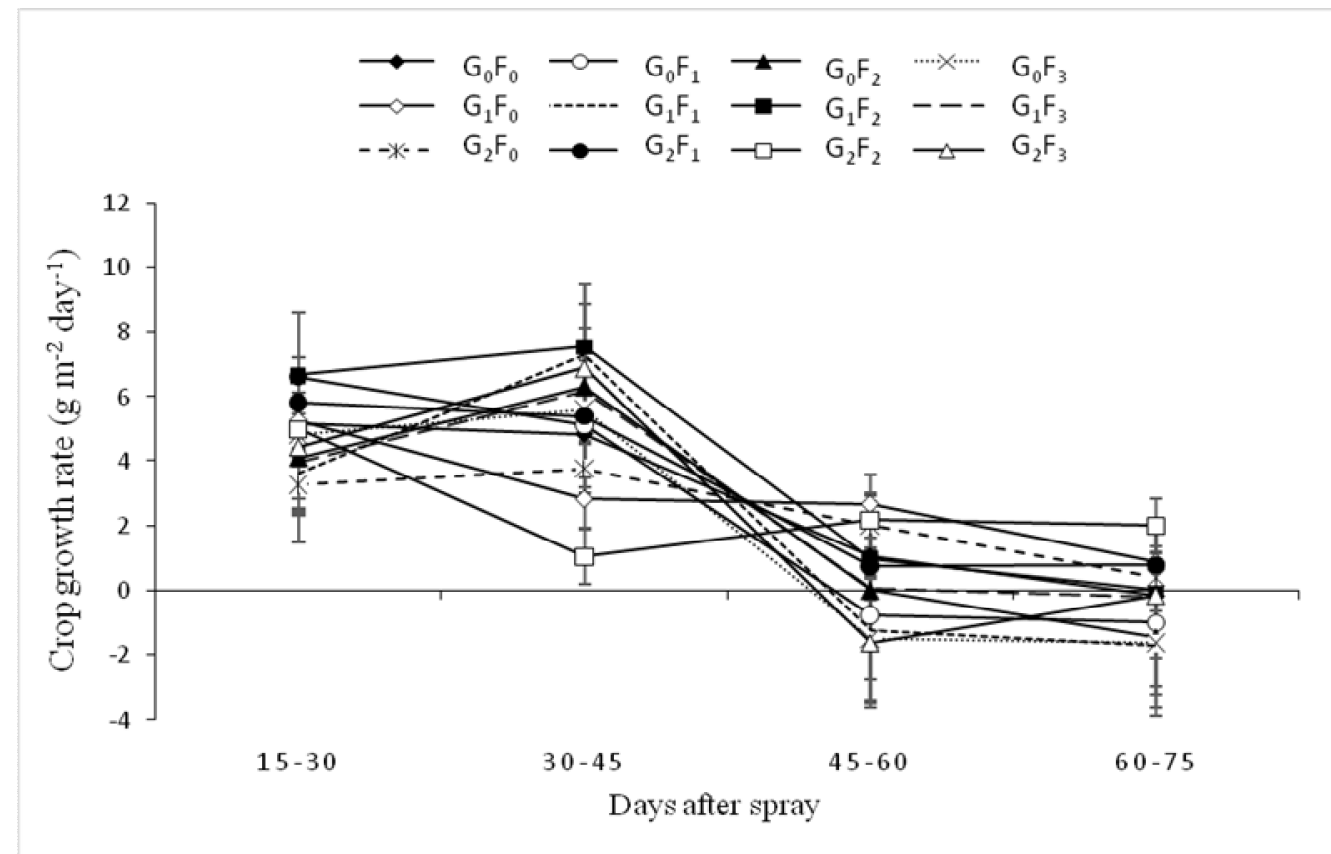

Fig. 1. Effect of NAA at different nitrogen levels on crop growth rate $\left(\mathrm{g} / \mathrm{m}^{2} /\right.$ day) of BARI GOM-26 at different days after spray (Mean $\pm \mathrm{SE})$.

Irrespective of the treatments, RGR was more at early stage (15 to 45 DAS) and showed a decreasing trend with the advancement of plant age (Fig. 2). The decrease in RGR was probably due to the increase in metabolically active tissue, which contributed less to the plant growth. It has also been suggested that the decrease in RGR could be attributed to shading of lower leaves by upper leaves ${ }^{(20)}$. Variations in RGR across the treatments were not apparent in the later growth period, but the differences were 
Table 2. Effect of NAA at different nitrogen levels on leaf area duration (LAD) of BARI GOM-26 at different days after spray.

\begin{tabular}{lllll}
\hline \multirow{2}{*}{ Treatments } & \multicolumn{4}{c}{ Days after spray (DAS) } \\
\cline { 2 - 5 } & $15-30$ & $30-45$ & $45-60$ & $60-75$ \\
\hline $\mathrm{G}_{0} \mathrm{~F}_{0}$ & $8.17 \mathrm{i}$ & $8.22 \mathrm{j}$ & $10.45 \mathrm{~h}$ & 12.14 \\
$\mathrm{G}_{0} \mathrm{~F}_{1}$ & $14.55 \mathrm{a}-\mathrm{g}$ & $16.61 \mathrm{a}-\mathrm{d}$ & $17.80 \mathrm{a}-\mathrm{d}$ & 17.13 \\
$\mathrm{G}_{0} \mathrm{~F}_{2}$ & $15.56 \mathrm{abc}$ & $17.63 \mathrm{ab}$ & $19.61 \mathrm{abc}$ & 19.06 \\
$\mathrm{G}_{0} \mathrm{~F}_{3}$ & $15.38 \mathrm{a}-\mathrm{d}$ & $15.52 \mathrm{a}-\mathrm{f}$ & $16.92 \mathrm{a}-\mathrm{f}$ & 18.12 \\
$\mathrm{G}_{1} \mathrm{~F}_{0}$ & $12.95 \mathrm{~b}-\mathrm{h}$ & $13.16 \mathrm{a}-\mathrm{i}$ & $15.39 \mathrm{a}-\mathrm{h}$ & 16.66 \\
$\mathrm{G}_{1} \mathrm{~F}_{1}$ & $15.30 \mathrm{a}-\mathrm{e}$ & $16.17 \mathrm{a}-\mathrm{e}$ & $17.04 \mathrm{a}-\mathrm{e}$ & 17.25 \\
$\mathrm{G}_{1} \mathrm{~F}_{2}$ & $17.13 \mathrm{ab}$ & $17.75 \mathrm{a}$ & $20.30 \mathrm{a}$ & 21.98 \\
$\mathrm{G}_{1} \mathrm{~F}_{3}$ & $14.64 \mathrm{a}-\mathrm{f}$ & $14.42 \mathrm{a}-\mathrm{g}$ & $15.08 \mathrm{a}-\mathrm{h}$ & 16.23 \\
$\mathrm{G}_{2} \mathrm{~F}_{0}$ & $11.00 \mathrm{e}-\mathrm{i}$ & $12.11 \mathrm{c}-\mathrm{j}$ & $13.78 \mathrm{~d}-\mathrm{h}$ & 14.71 \\
$\mathrm{G}_{2} \mathrm{~F}_{1}$ & $18.28 \mathrm{a}$ & $16.79 \mathrm{abc}$ & $20.23 \mathrm{ab}$ & 22.68 \\
$\mathrm{G}_{2} \mathrm{~F}_{2}$ & $12.51 \mathrm{c}-\mathrm{i}$ & $13.27 \mathrm{a}-\mathrm{i}$ & $16.13 \mathrm{a}-\mathrm{g}$ & 17.84 \\
$\mathrm{G}_{2} \mathrm{~F}_{3}$ & $11.85 \mathrm{c}-\mathrm{i}$ & $12.98 \mathrm{a}-\mathrm{j}$ & $14.85 \mathrm{a}-\mathrm{h}$ & 15.89 \\
$\mathrm{CV}(\%)$ & 37.61 & 35.87 & 35.55 & 36.56 \\
$\mathrm{LSD}(0.05)$ & 4.34 & 4.80 & 5.64 & $\mathrm{NS}$ \\
\hline
\end{tabular}

Means in a vertical column followed by same letter do not differ significantly at $5 \%$ level.

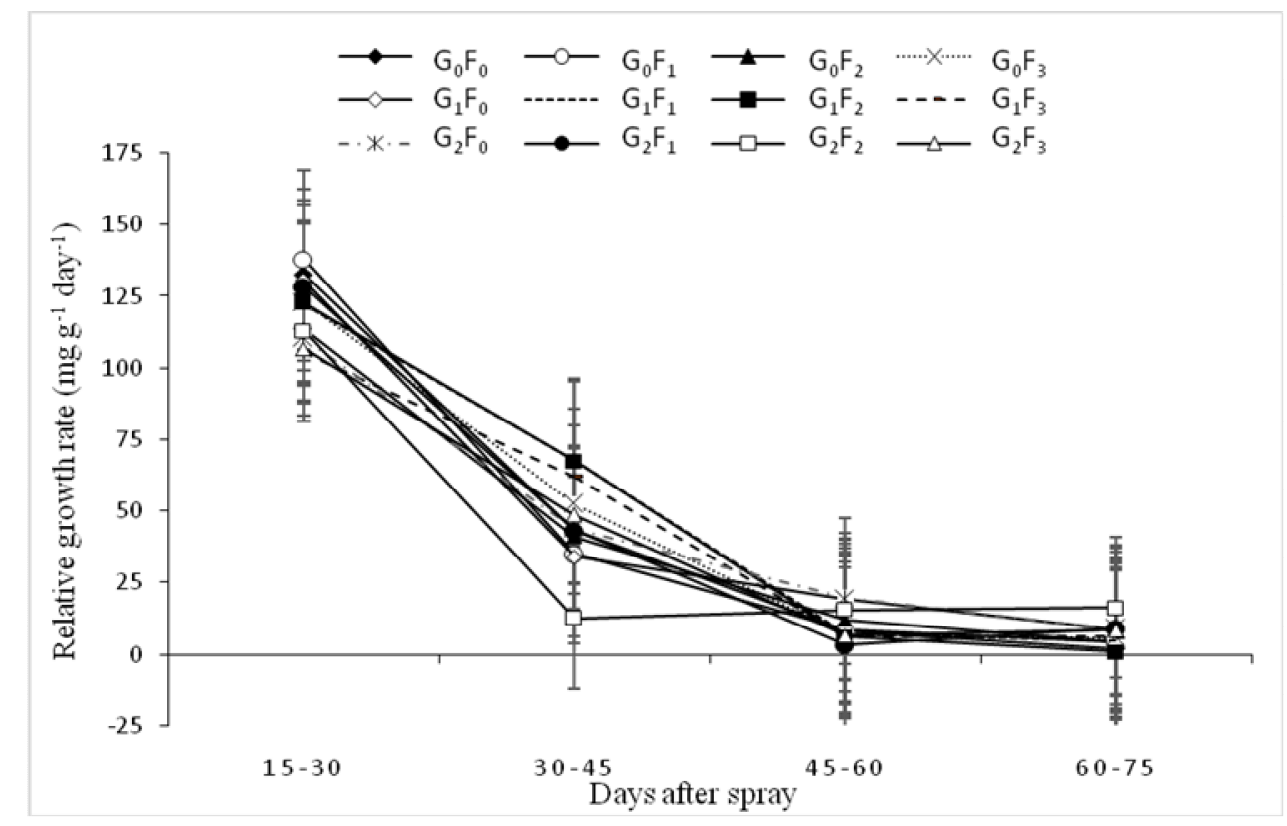

Fig. 2. Effect of NAA at different nitrogen levels on relative growth rate (mg/g/day) of BARI GOM26 at different days after spray (Mean \pm SE). 
were recorded from $50 \% \mathrm{~N}$-fertilizer alone and 25 ppm NAA in combination with $50 \%$ and $75 \% \mathrm{~N}$-fertilizer, respectively. RGR increased over the control due to all the treatments except $\mathrm{G}_{1} \mathrm{~F}_{2}$ during the period from 60 - 75 DAS. Jahan and Adam ${ }^{(9)}$ also reported higher RGR following NAA application at the early stages of growth for rice.

NAR represents plant photosynthetic efficiency. NAR was high in the earlier stages (15 - 30 DAS and 30 - 45 DAS) and thereafter decreased with advancement in the age of the crop (Fig. 3). The decrease in NAR at later stages of growth could be attributed to shading of lower leaves and increase in the number of older leaves which lost photosynthetic efficiency. At 30 - 45 DAS, NAR increased due to all the treatments from control except $\mathrm{G}_{1} \mathrm{~F}_{0}, \mathrm{G}_{2} \mathrm{~F}_{0}$ and $\mathrm{G}_{2} \mathrm{~F}_{2}$ and reached peak due to 25 ppm NAA in combination with $75 \% \mathrm{~N}$-fertilizer $\left(\mathrm{G}_{1} \mathrm{~F}_{2}\right)$. During 60 - 75 DAS, however, the only decrease was recorded due to $\mathrm{G}_{1} \mathrm{~F}_{2}$ treatment. Both increase and decrease in NAR following NAA application has also been reported in rice by Jahan and Adam ${ }^{(9)}$ and in chickpea by Karim and Fattah ${ }^{(8)}$.

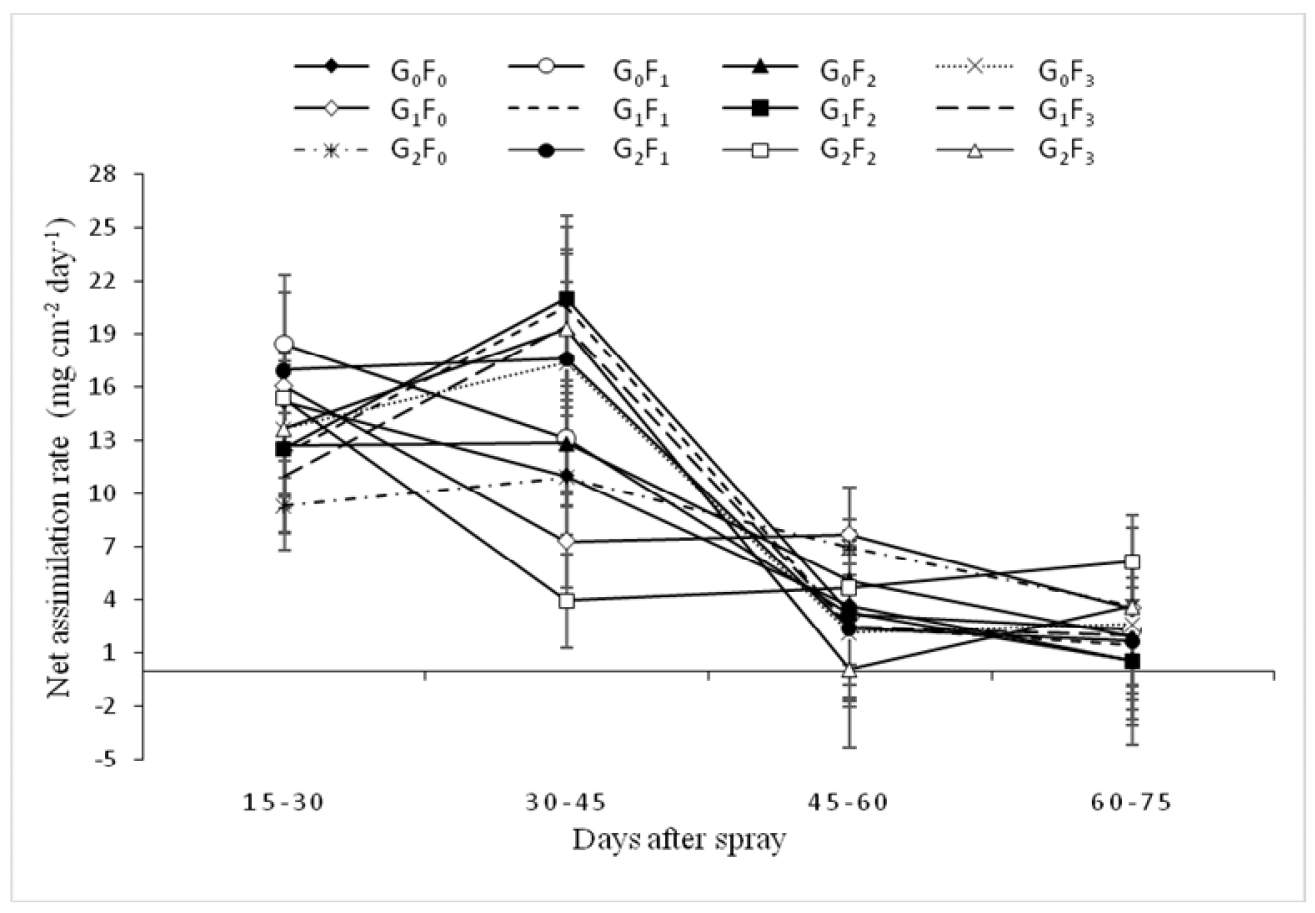

Fig. 3. Effect of NAA at different nitrogen levels on net assimilation rate $\left(\mathrm{mg} / \mathrm{cm}^{2} / \mathrm{day}\right)$ of BARI GOM-26 at different days after spray (Mean \pm SE).

The overall results of this investigation showed that NAA had both stimulatory and inhibitory effect on growth efficiency of plants and plants treated with NAA in combination with lower doses of N-fertilizer had higher LAI, CGR, RGR, NAR and LAD. 
Thus, lower doses of N-fertilizer along with foliar application of NAA could be as much effective as higher doses (100\%) of N-fertilizer application to increase growth and development of plants with higher values of physiological characteristics.

\section{References}

1. Gregory FG 1917. Physiological conditions in cucumber houses. 3rd Ann. Rep. Exptl. Res. Stn. Chestnut, 19-28.

2. Watson DJ 1952. The physiological basis of variation in yield. Advances in Agron. 4: 101-105.

3. Radford PJ 1967. Growth analysis formulae - their use and abuse. Crop Sci. 7: 171-175.

4. Ahad MA 1986. Growth analysis of rice bean (Vigna umbellate Thunb.) under different management practices and their agronomic appraisal. Ph.D. Dissertation in Agron. 21-22.

5. Srivastava BK and RP Sing 1980. Morpho-physiological response of garden pea (Pisum sativum L.) to sowing dates. II. Growth analysis. Indian J. Hort. 382-389.

6. Thakur DS and SR Patel 1998. Growth and sink potential of rice as influenced by the split application of potassium with FYM in inceptisols of eastern central India. J. Potassium Res. 14(1/4):73-77.

7. Katiyar RP 1980. Development changes in leaf area index and other growth parameters in chickpea. Indian J. Agric. Sci. 50: 684-691.

8. Karim MF and QA Fattah 2007. Growth analysis of chickpea cv. Bari chola-6 as affected by foliar spray of growth regulators. Bangladesh J. Bot. 36(2): 105-110.

9. Jahan $\mathrm{N}$ and Adam AMMG 2011. Comparative growth analysis of two varieties of rice following naphthalene acetic acid application. J. Bangladesh Acad. Sci. 35(1): 113-120.

10. Grewal HS and HS Gill 1986. Influence of NAA and nitrogen on the growth and yield of late planted paddy (Oryza sativa L.). J. Agril. Sci. 106:37-40.

11. Fertilizer Recommendation Guide 2012. Bangladesh Agricultural Research Council. Farmgate, Dhaka-1215. p. 274 .

12. Voldeng HD and Simpson GM 1967. The relationship between photosynthetic area and grain yield per plant in wheat. Can. J. Plant Sci. 470: 359-365.

13. Yoshida S, DA Forno, JH Cock and KA Gomez 1976. Laboratory manual for physiological studies of rice. IRRI, Manila, Philippines.

14. Watson DJ 1958. Leaf growth in relation to crop yield - The growth of leaves. Mithorpe (ed.) Butter worths, London.

15. Power JF, WO Willis and GA Reichman 1967. Effect of soil temperature, P and plant age on growth analysis of barley. Agron. J. 18: 459-463.

16. Williams RF 1946. The physiology of plant growth with special relation reference to the concept of net assimilation rate. Ann. Bot. 10: 41-72.

17. Steel RGD, JH Torrie and DA Dickey 1997. Principles and procedures of statistics. McGraw Hill Book Co. Inc. New York. pp. 666.

18. Patil PN, YC Panchal, S Manjunath and RV Koti 1990. Influence of plant growth regulators and micronutrients on growth and yield of chickpea (Cicer arietinum L.). J. Res. Andrhra Pradesh Agric. Univ. 18(1): 92-94. 
19. Surendra P, CM Nawalagatti, MB Chetti and SM Hiremath 2006. Effect of plant growth regulators and micronutrients on morpho-physiological and biochemical traits and yield in Okra. Karnataka J. Agric. Sci. 19(3): 694-697.

20. Thorne GN 1961. Effects of age and environment on net assimilation rate of barley. Ann. Bot. 25: $29-38$.

(Manuscript received on 16 January, 2016; revised on 24 April, 2016) 